\title{
Targeted Therapy in Systemic Sclerosis
}

\author{
Murray Baron, M.D.* \\ Chief Division of Rheumatology, Jewish General Hospital, Montreal, Quebec, Canada; and Professor of \\ Medicine, McGill University, Montreal, Quebec, Canada
}

\begin{abstract}
ABST RACT
Targeted therapies use an understanding of the pathophy siology of a disease in an individual patient. Although targeted therapy for systemic sclerosis (SSc, scleroderma) has not yet reach ed the levelof patientspecific treatments, recent developments in the understanding of the global pathophysiology of the disease have led to new treatments based on the cells and pathways that have been shown to be involved in the disease pathogenesis. The presence of a B cell signature in skin biopsies has led to the trial of rituximab, an anti-CD2O antibody, in SSc. The well-known properties of transforming growth factor (TGF)- $\beta$ in promoting collagen synthesis and secretion has led to a small trial of fresolimumab, a human IgG4 monoclonal antibody capable of neutralizing TGF- $\beta$. Evidence supporting important roles for interleukin- 6 in the pathogenesis of SSc have led to a large trial of toc ilizumab in SSc. Soluble guanylate cy clase (sGC) is an enzy me that catalyzes the production of cy clic guanosine monophosphate (cGMP) upon binding of nitric oxide (NO) to the sGC molecule. Processes such as cell growth and proliferation are regulated by cGMP. Evidence that SGC may play a role in SSc has led to a trial of riociguat, a molecule that sensitizes sGC to endogenous NO. Ty rosine kinases (TKs) are involved in a wide variety of phy siologic and pathological processes including vascular remodeling and fibrogenesis such as occurs in SSc. This has led to a trial of nintedanib, a next-generation ty rosine-kinase (TK) inhibitor which targets multiple TKs, in SSc.
\end{abstract}

KEY WORDS: Drug treatment, scleroderma, systemic sclerosis, targeted, therapy

\begin{abstract}
Abbreviations: A LK, anaplastic ly mphom a kinase; cGMP, cyclic guanosine m onophosphate; COMP, cartilage oligom eric protein; dcSSc, diffuse cutaneous sy stem ic sclerosis; EGFR, epidermal growth factor receptor; FVC, for ced vital capacity; G-kinases, protein kinases; GMP, guanosine monophosphate; IL-6, interleukin-6; ILD, interstitial lung disease; lcSSc, lim ited cutaneous sy stemic sclerosis; MRSS, modified Rodnan skin score; NO, nitric oxide; PDEs, phosphodiesterases; RTX, rituximab; sGC, soluble guanylate cyclase; SSc, sy stem ic sclerosis, scleroderma; TGF - $\beta$, transforming growth factor beta; THBS1, thrombospondin-1; TK, tyrosine kinase.

Cit ation: Ba ron M. Targeted Therapy in Sy stem ic Sclerosis. Rambam Ma imonides Med J 2 016;7 (4):eoo3o. doi:10.5041/RMMJ.10257 Review

Copy right: (C) 2016 Baron. This is an open-access article. All its content, except where otherwise noted, is distributed u n der the terms of the Creative Commons Attribution License (http://creativecommons.org/licenses/by/3.o), which per mits unrestricted use, distribution, and r eproduction in a ny medium, provided the original w ork is properly cited.
\end{abstract}

Conflict of interest: No potential conflict of in terest relevant to this article was reported.

* E-m ail: mbaron@rhu.jgh.mcgill.ca 


\section{INT RODUCTION}

Sy stemic sclerosis (SSc, or scleroderma) is a serious multi-sy stem disorder of connective tissue disease characterized clinically by thickening and fibrosisof the skin and involvement of internal organs, most commonly the lungs, gastrointestinal tract, and heart. Systemic sclerosis affects predo minantly women in the prime of their life and is associated with increased morbidity and mortality. Sy stemic sclerosis is a rare disease with prevalence estimates varying from 30 to $443 /$ million population. ${ }^{1,2}$

Because the disease is so heterogeneous and rare, it has been difficult to perform high-quality randomized controlled clinical trials. Unfortunately, the few such trials performed, especially early ones, have not been uniformly successful. Therapies studied in randomized controlled trials that have failedinclude ketanserin, 35 -fluorouracil, 4 ketotifen, 5 interferongamma, ${ }^{6}$ interferon-alpha, 7 penicillamine, ${ }^{8}$ relaxin, $, 9,10$ methotrexate, ${ }^{11}$ oral collagen, ${ }^{12}$ imatinib, ${ }^{13,14}$ IV IG, ${ }^{15}$ macitentan, ${ }^{16}$ and bosentan. ${ }^{17,18}$ More recently there have been some hopeful positive trials with statins, ${ }^{19}$ cyclophosphamide, ${ }^{20}$ and autologousstem cell transplantation. ${ }^{21,22}$

Could we be more successful with a more targeted approach to therapy in SSc, similar to that taken in other diseases such as cancer? For example, in melanoma, BRAF kinase-activating mutations can turn BRAF into an oncogene, and the presence of such mutations hasled to specific therapy. ${ }^{23}$ Similar analyses of non-small cell lung cancer has found that mutations in the epidermal growth factor receptor (EGFR), translocations involving the anaplastic ly mphoma kinase (ALK) tyrosine kinase, oncogenic RAS mutations, and other driver mutations, such as BRAF, can be treated with therapy targeted at these abnormalities. ${ }^{24}$

In SSc we are entering a very exciting and hopeful era with 316 trials for SSc listed on ClinicalTrials.gov. ${ }^{25}$ Some of these trials have used, or are using, new biologic agents or kinase inhibitors such as abatacept, ${ }^{26}$ rituximab, 25 imatinib, dasatinib, fasudil, 27 nintedanib, ${ }^{28}$ and fresolimumab, an antitransforming growth factor (TGF) antibody. ${ }^{29} \mathrm{~A}$ phase III trial of tocilizumab is underway. Some of these trials are based on the concept of targeting specific pathophysiologic abnormalities that have been found in SSc. We have thus hopefully moved away from general immunosuppressives such as cyclophosphamide or methotrexate to drugs that inhibit specific pathways or cells thoughttobe active in SSc. These represent the first steps toward personalized targeted medicine in SSc.

\section{RIT UXIMAB}

One promising approach to possiblebiomarkers that may indicate that a certain subset may respond to specific targeted therapy has come from the study of the gene expression found in skin biopsies. ${ }^{29-37}$ Early work demonstrated that some patients with SSc had a skin gene expression signature consistent with the presence of active B cells. ${ }^{31}$ This observation has led directly to two trials of rituximab (RTX), an anti-CD2O monoclonal antibody, in SSc. 38,39 In the first publication 15 patients with diffuse cutaneous sy stemic sclerosis (dcSSc) received two doses of rituximab $1 \mathrm{~g}$ each, 2 weeks apart. 39 The mean change in the modified Rodnan skin score (MRSS) between baseline and 6 months was not significant. Results of pulmonary function tests and other measures of major organ inv olvement were stable. The modest B cell infiltrates that were present in most skin biopsy specimens at baseline were completely depleted at 6 months in mostpatients. In the other trial, 14 patients with SSc were evaluated. ${ }^{8}$ Eight patients were randomized to receive two cy cles of RTX at baseline and 24 weeks, whereas six patients (control group) received standard treatment alone. There was a signific ant increase of forced vital capacity (FVC) in the RTX group compared with baseline. The median percentage of improvement of FVC in the RTX group was $10.25 \%$, whereas that of deterioration in the controls was $5.04 \%(P=0.002)$. Skin thickening, assessed with the MRSS, improved significantly in the RTX group compared with the baseline score (mean \pm SD $13.5 \pm 6.84$ versus $8.37 \pm 6.45$ at baseline versus 1 year, respectively, $P<0.001)$. Rituximab depleted both circulating $B$ cells and dermal B cells. In the RTX-treated group, there was a significant reduction of collagen deposition in the papillary dermis at 24 weeks compared with baseline which was not seen in the control group. The EUSTAR group also published an observational study assessing the effects of RTX on skin and lung fibrosis in patients with SSc. 40 Comparison between RTX-treated patients and matched controls revealed a significant differencein fav or of RTX. However, to this author's knowledge, rituximab has not strictly been employed as targeted therapy such as treating only those patients with a skin biopsy showing Bcell activation or analyzing the results in patients with skin biopsies thatshow B cell activation versus those with no such pattern. 


\section{FRESOLIMUMAB}

It is well-known that TGF- $\beta$ promotes collagen sy nthesis, secretion, processing, and cross-linkingas well as secretion of other matrix molecules, such as fibronectin and thrombospondin. ${ }^{41}$ This has led to an interest in using anti-TGF- $\beta$ in SSc. The first trial of CAT-192, a recombinant human antibody that neutralizes TGF- $\beta 1$, was not successful. ${ }^{2}$ However, a more recent study tested fresolimumab, a first-inclass human IgG4 $\mathrm{\kappa}$ monoclonal antibody capableof neutralizing all mammalian isoforms of TGF- $\beta .29$ There is a four-gene, pharmacodynamic biomarker of SSc skin disease, based on gene expression in a mid-forearm skin biopsy. ${ }^{29}$ Two of the four genes making up the biomarker, thrombospondin-1 (THBS1) and cartilage oligomeric protein (COMP), are highly regulated by TGF- $\beta$. In this open uncontrolled trial, the predefined primary efficacy outcome was change in COMP and THBS1 mRNA expression in skin after treatment compared with that at baseline. Subjects showed rapid declines in THBS1 and COMP gene ex pression in skin biopsies after treatment with fresolimumab. THBS1 and COMP gene expression was strikingly higher in SSc patient cohorts than in healthy control skin, and changes in gene expression in study patients generally correlated with changes in MRSS.

\section{T OCILIZUMAB}

Another promising therapy consists of inhibition of interleukin (IL)-6. Evidence supports important roles for IL-6 in the pathogenesis of SSc, e.g. dermal fibroblasts from SSc patients constitutively express higher lev els of IL-6 than found in healthy controls; serum and skin levels of IL-6 are elevated in SSc patients with early disease and in patients with SSc or SSc-interstitial lung disease (ILD), and increased IL-6 levels have been asso ciated with highermortality, more severe skin involvement, and increased incidence of progressive pulmonary decline. $43-48$ Strategies to block the IL-6 response resulted in a significant reduction of procollagen type I in cultured SSc fibroblasts and myofibroblastic differentiation in dermal fibroblasts in a bleomy cin-induced model of dermal sclerosis. 49,50 Some indirect evidence of increased effect of IL-6 in SSc derives from the fact that CRP is elevated in SSc although not to levels associated with diseases such as rheumatoid arthritis. ${ }^{51} \mathrm{C}$-reactive protein (CRP) levels in dcSSc are higher than in limited cutaneous SSc (lcSSc).51,52
These findings have led to a phase II trial of tocilizumab in early dcSSc. 53 The primary end-point showed a treatment difference of -2.70 MRSS units in favor of tocilizumab at week 24 but did not quite reach statistical significance. Ex ploratory analysis of lung function showed that fewer patients in the tocilizumab arm had a decline in percentagepredicted forced vital capacity than in the placebo arm by comparison of the cumulativedistribution by week 48 . Tocilizumab specifically downregulated the expression of myeloid-associated genes in the skin and decreased circulating levels of CCL18, a chemokine associated with fibrosis and progression of SSc-associated lung disease. A phase III trial is underway.

\section{RIOCIGUAT}

Soluble guanylate cyclase (sGC) is an enzy me that catalyzes the production of cyclic guanosine monophosphate (cGMP) upon binding of nitric oxide (NO) to the sGCmolecule. Once released by the sGC, cGMP can act as a second messenger to activate further downstream targets, such as cGMP-regulated ion channels, protein kinases (G-kinases), and phosphodiesterases (PDEs). Through those effectors, cGMP regulates a variety of physiological processes, including cell growth and proliferation, vascular tone and remodeling, immune responses, and neuronal transmission. Riociguat is a molecule that sensitizes sGC to endogenous NOby stabilizing NOsGC binding. 54,55 Riociguat also directly stimulates sGC, independent of NO, resulting in increased generation of cGMP. Riociguat has been shown in large randomized controlled clinical trials to be effective in patients with different forms of pulmonary hypertension including patients with SScrelated pulmonary arterial hy pertension $(\mathrm{PAH})$.

There is evidence that sGC may play a role in SSc. Soluble guany late cyclase activators inhibited the release of TGF- $\beta$-induced extracellular matrix proteins from primary dermal fibroblasts obtained from both normal volunteers and SSc subjects, and dermal fibrosis was reduced in the bleomycin skin fibrosis model of SSc . 56,57 Riociguat has been shown in large randomized controlled clinical trials to be effective in patients with different forms of pulmonary hypertension, including patients with SScrelated $\mathrm{PAH}, 5^{8}$ and is now in a trial for the skin thickening of SSc. 


\section{NINT EDANIB}

The last molecule that we will briefly address is nintedanib, a next-generation, potent, indolinonederived small molecule tyrosine-kinase (TK) inhibitor which targets multiple TKs. 59-61 Tyrosine kinases are involved in a wide variety of physiologic and pathological processes including vascular remodeling and fibrogenesis. Nintedanibleads to inhibition of several central molecules involved in fibroblast activ ation such as PDFGR- $\alpha$ and PDFGR- $\beta$, FGFR-1, FGFR-2, FGFR-3, VEGFR-1, VEGFR-2, VEGFR-3, and Src.

Nintedanib reduced differentiation of myofibroblasts and the release of collagen of dermal fibroblasts from patients with SSc and healthy individuals. Nintedanib also showed anti-fibrotic effects in a dose-dependent manner in different animal models of SSc, including the bleomycin skin fibrosis model both in preventive and therapeutic applications, the chronic graft-versus-host disease model, and the Tsk-1 model. Interestingly, in the Fra-2 tg mouse model, nintedanib did not only inhibit skin andlung fibrosis but also improved the pulmonary vascular lesions resembling PAH. ${ }^{61}$ Based on these results, a large, randomized, placebo-controlled trial with nintedanib is currently initiated in patients with SSc for pulmonary fibrosis.

\section{CONCLUSION}

Although we are in an exciting new era of drug trials for SSc, and although the drugs discussed here are being used because of their abilities to interfere with specific cells or pathways that have been found to be involved in SSc or SSc models, the field of targeted therapy has not y et progressed quite as far as it has in cancer. The nextbig step will be to understand if the new drugs are effectiv e specifically in patients who demonstrate abnormalities of the cells or pathways that are inhibited or activated by these new medications. Then we will be closer to developing a truly personalized approach to the treatment of this serious disease.

\section{REFERENCES}

1. Bernatsky S, Joseph L, Pineau CA, Belisle P, Hudson M, Clarke AE. Scleroderma prevalence: demographic $\mathrm{v}$ ariations in a population-based sample. Arthritis Rheum 2009;61:400-4. Full Text

2. Chifflot H, Fautrel B, Sor det C, Chatelus E, Sibilia J. Incidence and prev alence of sy stemic sclerosis: a sy stematicliterature review. Semin Arthritis Rheum 2 008;37:223-35. Full Text

3. Ortonne JP, Torzuoli C, Dujardin P, Fraitag B. Ketanserin in the treatment of sy stemic sclerosis: a double-blind controlled trial. Br J Dermatol 1989; 120:261-6. Full Text

4. Casas JA, Saway PA, Villarreal I, et al. 5-fluorouracil in the treatment of scleroderma: a randomised, double blind, placebo controlled international collaborativ estudy. Ann Rheum Dis1990;49:926-8. Full Text

5. Gruber BL, Kaufman LD. A double-blind randomized controlled trial of ketotifen versus pla cebo in early diffu se scleroderma. Arthritis Rheum1991;34:362-6. $\underline{\text { Full Text }}$

6. Polisson RP, Gilkeson GS, Py un EH, Pisetsky DS, Smith EA, Simon LS. A multicenter trial of recom binant human interferon gamma in patients with sy stem ic sclerosis: effects on cutaneous fibrosis and interleukin 2 receptor levels. J Rheumatol 1996;23:654-8.

7. Black CM, Silman AJ, Herrick AI, et al. Interferonalpha does not improve outcome at one year in patients with diffuse cutaneous scleroderma: results of a randomized, double-blind, placebo-controlled trial. Arthritis Rheum 1999;42:299-305. Full Text

8. Clem ents PJ, Seibold JR, Furst DE, et al. High-dose versus low-dose D-penicillamine in early diffuse sy stemic sclerosis trial: lessons learned. Semin Arthritis Rheum 2004;33:249-63. Full Text

9. Seibold JR, Korn JH, Simms R, et al. Recombinant human relaxin in the treatment of scleroderma. A randomized, double-blind, pla cebo-controlled trial. Ann Intern Med 2000;132:871-9. Full Text

10. Khanna D, Clements PJ, Furst DE, et al. Recombinant human relaxin in the treatment of sy stem ic sclerosis with diffuse cutaneous involv ement: a randomized, double-blind, pla cebo-controlled trial. Arthritis Rheum 2009;60:1102-11. Full Text

11. Pope JE, Bellamy N, Seibold JR, et al. A r andomized, controlled trial of m ethotrexate versus placebo in early diffuse scleroderma. Arthritis Rheum2001;44: 1351-8. Full Text

12. Postlethwaite AE, Wong WK, Clements P, et al. A multicenter, randomized, double-blind, placebocontrolled trial of oral type I collagen treatm ent in patients with diffuse cutaneous systemic sclerosis: I. oral ty pe I collagen does not improve skin in all patients, but may improve skin in late-phase disease. Arthritis Rheum 2008;58:1810-22. Full Text

13. Pope $J, M c B a i n ~ D$, Petrlich L, et al. Im atinib in active diffu se cutaneous systemic sclerosis: results of a sixmonth, randomized, double-blind, placebo-controlled, proof-of-concept pilot study at a single center. Arthritis Rheum 2011;63:3547-51. Full Text 
14. Prey S, Ezzedine K, Dou ssau A, et al. Im atinib mesy late in scleroderma-associated diffuse skin fibrosis: a phase II multicentre randomized double-blinded controlled trial. Br J Dermatol 2012;167:1138-44. Full Text

15. Takehara K, Ihn H, Sato S. A randomized, doubleblind, placebo-controlled trial:intravenous immunoglobulin treatment in patients with diffuse cutaneous sy stemic sclerosis. Clin Exp Rheumatol 2013;31:1516.

16. Khanna D, Denton CP, Merkel PA, et al. Effect of macitentan on the dev elopment of new ischemic digital ulcers in patients with sy stemic sclerosis: DUAL-1 and DUAL-2 randomized clinical trials. JAMA 2016;315:1975-88. Full Text

17. Seibold JR, Denton CP, Furst DE, et al. Randomized, prospective, placebo-controlled trial of bosentan in interstitial lung disease secondary to systemic sclerosis. Arthritis Rheum 2010;62:2101-8. Full Text

18. Korn JH, Mayes M, Matucci Cerinic M, et al. Digital ulcer s in systemic sclerosis: prevention by treatment with bosentan, an or al endothelin receptor antagonist. Arthritis Rheum 2004;50:3985-93. Full Text

19. Abou-Ray a A, Abou-Ray a S, Helmii M. Statins: potentially u seful in therapy of sy stem ic sclerosisrelated Raynaud's phen omen on and digital ulcers. $J$ Rheumatol 2008;35:1801-8.

20. Tashkin DP, Elash off R, Clements PJ, et al. Cy clophosphamide versus placebo in scleroderma lung disease. N Engl J Med 2 006;354:2655-66. Full Text

21. Burt RK, Shah SJ, Dill K, et al. Autologous nonmyeloablative haemopoietic stem-cell transplantation com pared with pulse cy clophosphamide once per m onth for systemic sclerosis (ASSIST): an open-label, randomised phase 2 trial. Lancet 2011;378:498-506. Full Text

22. van Laar JM, Farge D, Sont JK, et al. Autolog ous hem atopoietic stem cell transplantation v s intrav en ous pulse cycloph osphamide in diffuse cutaneous sy stemic sclerosis: a ran domized clinical trial. JAMA 2014;311:2490-8. Full Text

23. Wellbrock C, HurlstoneA. BRAF as therapeutic target in melanom a. Biochem Pharmacol 2010;80:561-7. Full Text

24. Janne PA, Shaw AT, Pereira JR, et al. Selum etinib plus docetaxel for KRAS-mutant advanced nonsmall-cell lung cancer: a randomised, multicentre, placebo-controlled, phase 2 study. Lancet Oncol 2013;14:38-47. Full Text

25. Clinical Trials Gov. 2016. Systemic sclerosis. Av ailable at: http://bit.ly/2cQnXdi.
26. Clinical Trials Gov . Abatacept Scleroderma. 2016. Av ailable at: http://bit.ly /2cxxGEI.

27. Clinical Trials Gov. Scleroderma Rituximab Trials. 2016. Available at: http://bit.ly/2c98110.

28. Minier T, Pentek M, Brodszky V, et al. Cost-of-illness of patients with systemic sclerosis in a tertiary care centre. Rheumatology (Oxford) 2010;49:1920-8. Full $\underline{\text { Text }}$

29. Rice LM, Padilla CM, McLaughlin SR, et al. Fresolim umabtreatment decreases biomarkers and im proves clinical sy m ptom $\mathrm{s}$ in sy stemic sclerosis patients. J Clin Invest 2015;12:2795-807. Full Text

30. Chakravarty EF, Martyanov V, Fiorentino D, et al. Gen e expression changes reflect clinical response in a placebo-controlled randomized trial of abatacept in patients with diffuse cutaneous system ic sclerosis. Arthritis Res Ther 2015;17:159. Full Text

31. Whitfield ML, Finlay DR, Murray JI, et al. Systemic and cell type-specific gene expression patterns in scleroderma skin. Proc Natl Acad Sci U S A 2003; 100:12319-24. Full Text

32. Pendergrass SA, Whitfield ML, Gardner H. Understanding systemic sclerosis through gene expression profiling. Curr Opin Rheumatol 2007;19:561-7. Full Text

33. Sargent JL, Milano A, Connolly MK, Whitfield ML. Scleroderma gene expression and pathway signatures. Curr Rh eumatol Rep 2008;10:205-11. Full $\underline{\text { Text }}$

34. MilanoA, Pendergrass SA, Sargent JL, et al. Molecular subsets in the gene expression signatures of scler oderma skin. PLoS One 2008;3:e2696. Full Text

35. Chung L, Fior entino DF, Benbarak MJ, et al. Molecular framework for response to imatinibmesylate in sy stemic sclerosis. Arthritis Rheum 2009;60:584-91. Full Text

36. SargentJL, Milano A, Bhattacharyy a S, et al. A TGFbeta-respon sive en esignature is associated with a subset of diffuse scleroderma with increased disease sev erity. J Invest Dermatol 2010;130:694-705. Full $\underline{\text { Text }}$

37. Sargent J, Milano A, Bhattacharyya S, et al. A transforming growth factor $-\beta$ (TGF $\beta$ )-responsive gene signature predicts more severe skin disease and occur rence of in terstitial lung disease (ILD) in diffuse cutaneou s systemic sclerosis (dcSSc) [Poster]. Nov . 6-11, 2007 Annual Scientific Meeting of the American College of Rheumatology; Boston, MA. Available

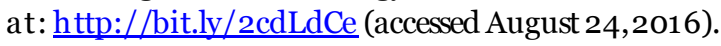

38. Daoussis D, Liossis SN, Tsamandas AC, et al. Experience with rituximab in scleroderma: results 
from a 1-year, proof-of-principle study. Rheumatology (Oxford) 2010;49:271-80. Full Text

39. Lafy atis R, Kissin E, YorkM, et al. B cell depletion with rituximab in patients with diffuse cutaneous sy stemic sclerosis. Arthritis Rheum 2009;60:578-83. Full Text

40. Jordan S, Distler JH, Maurer B, et al. Effects and safety of rituximabin systemic sclerosis: an analy sis from the European Scleroderma Trial and Research (EUSTAR) group. Ann Rheum Dis 2015;74:1188-94. Full Text

41. Varga J, Whitfield ML. Transforming growth factorbeta in systemic sclerosis (scleroderma). Front Biosci (Schol Ed) 2009;1:226-35. Full Text

42. Denton CP, Merkel PA, Furst DE, et al. Recombinant human anti-transforming growth factor beta1 antibody therapy in systemic sclerosis: a multicenter, randomized, placebo-controlled phase I/II trial of CAT-192. Arthritis Rheum 2007;56:323-33. Full Text

43. O'Reilly S, Ciechomska M, Cant R, HugleT,van Laar JM. Interleukin-6, its role in fibrosing conditions. Cy tokine Growth Factor Rev 2012;23:99-107. Full $\underline{\text { Text }}$

44. Khan K, Xu S, Nihty anova S, et al. Clinical and pathological significance of interleukin 6 overexpression in sy stemic sclerosis. Ann Rheum Dis 2012;71:1235-42. Full Text

45. KadonoT, Kikuchi K, Ihn H, Takehara K, Tamaki K. Increased production of interleukin 6 and interleukin 8 in scleroderma fibroblasts. J Rheumatol 1998; 25:296-301. Full Text

46. Schmidt K, Martinez-Gamboa L, Meier S, et al. Bronch oalveoloar lavage fluid cy tokin es and chemokines as markers and predictors for the outcome of interstitial lung disease in sy stemic sclerosis patients. Arthritis Res Ther 2009;11:R111. Full Text

47. Needlem an BW, Wigley FM, Stair RW. Interleukin-1, interleukin-2, interleukin-4, interleukin-6, tum or necrosis factor alpha, and in terferon-gammalevels in ser a from patients with scleroderma. Arthritis Rheum 1992;35:67-72. Full Text

48. Hasegawa M, Sato S, Fujimoto M, Ihn H, Kikuchi K, Takehara K. Serum lev els of interleukin 6 (IL-6), oncostatin M, soluble IL-6 receptor, and soluble gp130 in patients with systemic sclerosis. J Rheumatol 1998;25:308-13.

49. Kitaba S, Murota H, Terao M, et al. Blockade of interleukin-6 receptor alleviates disease in mouse model of scleroderma. AmJ Pathol 2012;180:165-76. $\underline{\text { Full Text }}$
50. Desallais L, Avouac J, Frechet M, et al. Targeting I-6 by both passiveor activeimmunization strategies prev ents bleomycin-induced skin fibrosis. Arthritis Res Ther 2014;16:R157. Full Text

51. Muangchan C, Harding S, Khimdas S, Bonner A, Baron M, Pope J. Association of C-reactive protein with high disease activity in sy stemic sclerosis:results from the Canadian Scleroderma Research Group. Arthritis Care Res (Hoboken) 2012;64:1405-14. Full Text

52. Liu X, Mayes MD, Pedroza C, et al. Does C-reactive protein predict the long-term progression of interstitiallung disease and survival in patients with early sy stemic sclerosis? Arthritis Care Res (Hoboken) 2013;65:1375-80. Full Text

53. Khanna D, Denton CP, Jahreis A, et al. Safety and efficacy of subcutaneou s tocilizumab in adults with sy stemic sclerosis (faSScinate): a phase 2, random ised, controlled trial. Lancet 2016;387:2630-40. Full $\underline{\text { Text }}$

54. Belik J. Riociguat, an or al soluble guanylate cyclase stimulator for thetreatment of pulm onary hy pertension. Curr Opin Investig Drugs 2 009;10:971 -9.

55. Mittendorf J, Weigand S, Alonso-Alija C, et al. Discov ery of riociguat (BAY 63-2521): a potent, oral stim ulator of soluble guanylate cyclase for the treatment of pulmonary hypertension. Chem MedChem 2009;4:853-65. Full Text

56. Bey er C, Reich N, Schindler SC, et al. Stimulation of soluble guanylate cy clase reduces experimental derm al fibrosis. Ann Rheum Dis 2 012;71:1019-26. Full Text

57. Dees C, Bey er C, Distler A, et al. Stimulators of soluble guanylate cyclase (sGC) inhibit experimental skin fibrosis of different aetiologies. Ann Rheum Dis 2015;74:1621-5. Full Text

58. Ham bly N, Granton J. Riociguat for thetreatment of pulmonary hypertension. Expert Rev Respir Med 2015;9:679-95. Full Text

59. Antoniu SA, Kolb MR. Intedanib, a triple kinase inhibitor of VEGFR, FGFR and PDGFR for the treatment of cancer and idiopathic pulmonary fibrosis. IDrugs $2010 ; 13: 332-45$.

6o. Roth GJ, Binder R, Colbatzky F, et al. Nintedanib: from discovery to the clinic. J Med Chem 2015;58:1053-63. Full Text

61. Wollin L, Wex E, Pautsch A, et al. Mode of action of nintedanib in the treatment of idiopathic pulmonary fibrosis. Eur Respir J 2015;45:1434-45. Full Text 